\title{
KONFLIK INTERNASIONAL TERHADAP SUMBER ENERGI (PENYEBAB DAN KONSEKUENSI)
}

\author{
Heri sunandar \\ Sekolah Tinggi Ilmu-ilmu Sosial (stis) Tual \\ Email: heri01@gmail.com
}

\begin{abstract}
Abstrak
Artikel ini membahas tentang konflik internasional atas sumber energi (minyak, gas dan air), dengan alasan bahwa ketiga sumber tersebut merupakan inti kehidupan ekonomi, politik dan sosial bagi semua negara di dunia. Semua studi dan prakiraan spesialis di bidang ketahanan energi, menegaskan bahwa konflik atas sumber energi tidak dapat dihindari karena meningkatnya permintaan global yang mengarah pada pertumbuhan ekonomi yang lebih tinggi dan keragaman populasi dunia yang tinggi dan karena meningkatnya persaingan untuk sumber energi oleh yang baru. negara-negara berkembang seperti Cina dan India, persaingan ini, yang akan berubah menjadi konflik internasional yang tidak dapat dihindari di masa depan, jadi artikel ini menjelaskan penyebab konflik ini dan hasil masa depan pada hubungan internasional

Kata kunci: Ketahanan Energi, Konflik Internasional, Persaingan, Sumber Daya Energi, Minyak, Gas, Air.
\end{abstract}

\begin{abstract}
This article discusses international conflicts over energy sources (oil, gas and water), arguing that these three sources are the core of economic, political and social life for all countries in the world. All studies and forecasts of specialists in the field of energy security, confirm that conflicts over energy sources are inevitable due to increasing global demand leading to higher economic growth and high diversity of world population and due to increased competition for energy sources by new ones. developing countries like China and India, this rivalry, which will turn into an unavoidable international conflict in the future, so this article describes the causes of this conflict and the future results on international relations.
\end{abstract}

Keywords: Energy Security, International Conflict, Competition, Energy Resources, Oil, Gas, Water.

\section{A. PENDAHULUAN}

Sejak awal abad ini, energi mengambil tempat sentral untuk pembangunan ekonomi dan kemajuan sosial bangsa-bangsa di seluruh dunia. Energi adalah segalanya

JURNAL PAPATUNG: Vol. 2 No. 1 Tahun 2019

ISSN: 2715-0186 
di era modern, terutama Minyak dan gas adalah Mesin kehidupan untuk hampir semua mesin untuk bergerak dan untuk produksi, transportasi, makanan, untuk pergerakan kendaraan, pesawat terbang dll. Kita hidup di era energi. Minyak adalah bahan terpenting bagi kehidupan kita, untuk industri, untuk pembangunan ekonomi, untuk kemakmuran kita, tetapi sayangnya kita menghadapi krisis energi global dengan cadangan alam yang cepat habis karena konsumsi yang berlebihan, minyak pernah menjadi sumber kekayaan manusia, tetapi berubah menjadi "Air Mata Iblis", Perebutan kendali atas sisa cadangan energi dunia memuncak, dan sampai pada konflik berdarah, perang di Irak, adalah contoh terbaru. Juga Asia Tengah yang dikenal sebagai "lubang hitam di tanah" karena peristiwa-peristiwa di abad terakhir, misalnya, Laut Kaspia mengandung minyak dan gas dalam jumlah terbesar, dan membentang hampir tanpa akhir. Cadangan minyak diperkirakan mencapai 100 miliar barel minyak mentah di Republik Kazakhstan dan Azerbaijan saja1. Itu dipasang piket dan alat peraga untuk menetapkan aturan dan penyebaran. Dalam upaya untuk menghilangkan ketergantungan pada sumber energi asing yang terancam, Amerika Serikat memulai intervensi baru dalam konflik melawan Rusia, China dan Iran untuk menguasai wilayah Laut Kaspia dan sumber daya dan metode yang muncul dari pipa, Oleh karena itu, pusat konflik internasional di bidang minyak dan gas terletak pada tiga bidang berikut:

- Laut Kaspia (dengan negara-negara sekitarnya Kazakhstan, Turkmenistan, Iran dan Azerbaijan)

- Asia Tengah (termasuk Kazakhstan, Uzbekistan, Tajikistan, Kyrgyzstan, Turkmenistan, Afghanistan, Pakistan dan ke Cina dan India)

- Negara-negara Teluk Persia dan Arab (Oman, Uni Emirat Arab, Qatar, Arab Saudi, Irak dan Iran). Ketiga wilayah geografis ini akan menjadi pusat konflik internasional saat ini dan yang akan datang, karena wilayah tersebut mengandung minyak dan gas terbesar cadangan di dunia, Pada tahun 2002, negara-negara Teluk Persia Bahrain, Iran, Irak,

Kuwait, Qatar, Arab Saudi, dan UEA, menghasilkan sekitar 25\% minyak dunia, memegang hampir dua pertiga dari cadangan minyak mentah dunia, dan sekitar $35 \%$ dari cadangan gas alam dunia2, Kekayaan wilayah ini dalam energi sumber daya akan menyebabkan persaingan internasional untuk menguasai wilayah ini, persaingan ini akan terjadi antara kekuatan tradisional besar seperti Amerika, Inggris dan Rusia di satu sisi dan antara yang baru muncul seperti Cina dan India, persaingan ini dapat diperburuk dengan Meningkatnya permintaan akan sumber daya energi akibat 
pertumbuhan penduduk dan pertumbuhan ekonomi yang cepat dan dapat menimbulkan konflik dan bentrokan di masa depan.

Aspek lain dari konflik internasional atas energi terletak pada perebutan pipa gas dan minyak, antara negara pengekspor dan negara transit, seperti (sengketa Rusia Ukraina) untuk pasokan gas Rusia ke Eropa Barat, di mana Rusia memasok sekitar seperempat gas yang dikonsumsi di Eropa dan sekitar $80 \%$ gas ini melewati tanah Ukraina sebelum tiba di EU3, Pada bulan Januari 2009, ketidaksepakatan ini mengakibatkan gangguan pasokan di banyak negara Eropa, dengan delapan belas negara Eropa melaporkan penurunan besar atau pemutusan total pasokan gas mereka diangkut melalui Ukraina dari Rusia, pada bulan Oktober 2009, ketidaksepakatan lain muncul tentang jumlah gas yang akan diimpor Ukraina dari Rusia pada tahun 2010. Sengketa dan ketegangan tentang transfer gas antara Rusia dan Ukraina ini jika terjadi lagi dapat menyebabkan pengurangan $25 \%$ dari pasokan gas Uni Eropa, dan ini menyebabkan krisis gas di Eropa, mungkin mencerminkan ke semua pasar dunia, Perbedaan seperti itu bertaruh Misalnya negara-negara pengekspor energi dan antar negara transit dapat menyebabkan konflik di masa depan di tingkat internasional.

Selain geopolitik memainkan peran penting dalam memicu konflik internasional atas energi, sisi ekonomi dalam perang Amerika di Afghanistan adalah untuk mengamankan impor energi yang berasal dari Asia Tengah dan kemungkinan perluasan jaringan pipa untuk mengangkut sumber daya energi dari Laut Kaspia melalui Afghanistan ke Arab. Laut dan kemudian ke Samudra Hindia dan Laut Merah, Wilayah laut Kaspia dianggap sebagai salah satu aria terpenting dalam produksi energi dunia, di mana statistik menunjukkan berdasarkan perkiraan oleh BP dan Administrasi Informasi Energi (EIA), Departemen Energi AS. Wilayah Kaspia menghasilkan 1,9 juta barel per hari5 (bbls / hari) termasuk cairan gas alam pada tahun 2005, atau 2\% dari total output dunia, memiliki cadangan minyak dan gas yang besar, Dimana Dari Agustus 2009 hingga Agustus 2010 Iran ditemukan 13 baru ladang minyak dan gas dengan total cadangan 14 miliar barel minyak dan 45 triliun kaki kubik (1,3 triliun meter kubik) gas, tetapi terkurung daratan, minyak dan gas alam harus diangkut melalui pipa ke terminal di laut terbuka, di mana itu akan dipompa ke kapal tanker dan dikirim ke pelanggan. Proyek semacam itu juga menghadapi kendala besar. Jarak yang jauh di atas pegunungan dan gurun yang seringkali tidak ramah, rawan gempa bumi, dan rentan terhadap serangan, akan membuat pembangunan dan pengoperasian pipa menjadi lebih sulit. Tetapi politik, bukan alam, yang menjadi rintangan terbesar. Semua pipa gas dan minyak yang bisa dibangun bisa bermasalah di segala arah.

JURNAL PAPATUNG: Vol. 2 No. 1 Tahun 2019

ISSN: 2715-0186 
Iran: tidak dapat membuat proyek ekonomi dengan Iran karena sanksi ekonomi AS yang mencegah pembuatan proyek ini di Iran.

Azerbaijan: juga tidak dapat berurusan dengan Azerbaijan karena embargo ekonomi oleh AS setelah intervensi di Armenia pada awal 1990.

Kaukasus: Telah terjadi pertempuran sengit dalam beberapa tahun terakhir karena Moskow memerangi pemberontak di Chechnya,

Asia Tengah: Saat perang saudara di Tajikistan secara resmi berakhir pada tahun 1997, pertempuran antara pemerintah dan pemberontak terkadang meletus. Uzbekistan baru-baru ini memerangi pemberontak Islam yang berbasis di negara tetangga Kirgistan.

Turki: masih menderita masalah Kurdi dan perjuangan terus-menerus dengan mereka selama lebih dari 40 tahun, itu telah meningkat pada periode terakhir setelah peristiwa kekerasan yang dialami Suriah hari ini, Jadi kita dapat memahami dimensi ekonomi perang AS di Afghanistan dan pentingnya membangun jaringan pipa minyak dan gas melalui Afghanistan ke Laut Arab.

Di sisi lain, konflik atas air tidak kalah pentingnya dengan konflik minyak dan gas, tiga faktor akan mempercepat kelangkaan air: percepatan pembangunan ekonomi, pertumbuhan penduduk dan perubahan iklim, Para ahli mengatakan bahwa separuh umat manusia akan berada di tahun 2030 hidup di wilayah yang kekurangan air dan mereka akan menghadapi konfrontasi dengan penyebab air yang menimbulkan perselisihan dan konflik atas sumber daya air6. Konflik dapat disebabkan oleh penggunaan air yang meliputi penggunaan militer, industri, pertanian, rumah tangga, dan politik. Melalui penggunaan militer dan politik, konflik dapat diperburuk dengan penggunaan sistem air sebagai senjata dan sebagai tujuan politik seperti sengketa Turki Suriah atas Sungai Efrat, Sengketa air yang berlangsung selama beberapa dekade yang hampir menyebabkan perang antara kedua negara di Untuk berbagi sumber daya sungai, di mana Turki menggunakan senjata air untuk menekan pemerintah Suriah, yang pada gilirannya mendukung kelompok oposisi Kurdi di Turki, banyak pengamat percaya bahwa air akan menjadi sumber utama konflik di masa depan dan setiap tetesan air akan lebih mahal dari setetes darah.

Pentingnya studi ini terkait dengan meningkatnya konflik internasional atas sumber daya energi, yang pada gilirannya merupakan cara yang hilang. Saat ini lebih dari 80\% kebutuhan energi global dipenuhi oleh bahan bakar fosil seperti minyak bumi, gas dan batubara. Sayangnya, cadangan global dari sumber-sumber yang langka dan

JURNAL PAPATUNG: Vol. 2 No. 1 Tahun 2019

ISSN: 2715-0186 
tidak dapat diperbarui ini sangat terbatas7. Cadangan minyak terbukti global diperkirakan mencapai 1.188 miliar barel (satu barel setara dengan 160 liter) pada akhir tahun 2004. Pada tahun yang sama, cadangan terbukti gas ditemukan sekitar 6400 triliun kaki kubik (satu triliun kaki kubik). setara dengan 100 juta barel bahan bakar cair) dengan Federasi Rusia memiliki bagian terbesar. Menurut beberapa perkiraan, diperkirakan bahwa waktu penipisan sekitar 40 hingga 60 tahun untuk minyak, sementara gas kemungkinan akan bertahan sedikit di atas 100 tahun. Oleh karena itu, banyak negara di dunia yang mengkhawatirkan keamanan pasokan energi di masa depan, terutama yang sangat bergantung pada impor untuk kebutuhan minyak dan gasnya. Seperti India. Skenario suram ini terkait dengan harga minyak saat ini sekitar US \$ 80 / bbl. telah menjadikan energi sebagai subjek yang sangat topic.

Ditambah dengan penipisan sumber daya ini yang akan segera terjadi dan dengan percepatan pertumbuhan ekonomi di banyak negara seperti India dan Cina yang muncul, internasional bersaing untuk mengontrol sumber energi di dunia persaingan ini yang mungkin berubah menjadi konflik bersenjata dalam waktu dekat. Dan hal inilah yang semakin mementingkan pengkajian ketahanan energi dalam hubungan internasional, khususnya di Timur Tengah yang menganggap tempat energi terpenting dunia dan poros perjuangan internasional.

\section{B. PEMBAHASAN}

\section{PERTAMA: KONSEP KONFLIK DALAM HUBUNGAN INTERNASIONAL}

Konsep konflik dan perang merupakan salah satu konsep tertua dalam hubungan internasional dan dapat dikatakan bahwa ilmu hubungan internasional didirikan karena mencari penyebab konflik, perang dan menjaga perdamaian, dimana muncul teori-teori tertua dalam hubungan internasional. (teori realisme dan idealisme) yang masingmasing memiliki perbedaan pandangan untuk mencegah perang dan memelihara perdamaian, teori realisme berpikir, kemungkinan mencapai perdamaian dapat dicapai melalui kekuatan militer dan keseimbangan kekuatan, sedangkan idealisme berpikir bahwa perdamaian dapat dicapai melalui kerjasama dan koordinasi dan melalui keadilan internasional.

Hukum internasional membedakan antara tiga bentuk konflik internasional, konflik bersenjata internasional, konflik bersenjata internasional, dan konflik bersenjata non-internasional. Menurut Konvensi Jenewa 1949, pasal umum 2 menyatakan bahwa

"semua kasus perang yang dideklarasikan atau konflik bersenjata apa pun yang

JURNAL PAPATUNG: Vol. 2 No. 1 Tahun 2019

ISSN: 2715-0186 
mungkin timbul antara dua atau lebih pihak kontrak tinggi, bahkan jika keadaan perang tidak diakui, konvensi tersebut juga akan berlaku untuk semua kasus pendudukan sebagian atau total wilayah pihak yang mengadakan kontrak tinggi bahkan jika pendudukan tersebut tidak menemui perlawanan bersenjata " (Konvensi Jenewa, 1949, pasal 2). Artinya bahwa terjadinya konflik bersenjata internasional sudah jelas, yaitu akan menjadi konflik antara angkatan bersenjata resmi dari dua negara yang berbeda. Contoh yang bagus adalah perang Korea Utara-Korea Selatan tahun 1950. Konflik kedua dikenal sebagai konflik bersenjata internasional: Ini adalah fenomena baru dalam hukum internasional, itu terjadi ketika Anda mendapatkan perang antara dua faksi yang bertikai atau lebih masing-masing dan masing-masing didukung oleh negara ketiga, misalnya perang saudara Lebanon di 1975, di mana banyak pihak bertikai, masing-masing pihak didukung oleh negara tetangga, seperti Suriah, Israel, Irak dan Mesir. Konflik bersenjata non-internasional, menurut pasal umum 3 Konvensi Jenewa, adalah „konflik bersenjata yang bersifat non-internasional yang terjadi di salah satu pihak yang terikat kontrak Tinggi, seperti perselisihan dan pemogokan domestik. Konsep konflik dalam literatur khusus politik dipandang "sebagai fenomena dinamis, konsep tersebut mengisyaratkan" posisi kompetitif tertentu, masing-masing pihak yang berinteraksi tidak sesuai dalam situasi potensial masa depan, karena masing-masing juga merasa harus mengambil sikap yang tidak sesuai dengan kepentingan yang dirasakan pihak lain, Jadi ada kecenderungan keluar untuk fokus pada posisi dimensi kompetitif dalam definisi konflik karena itu adalah "bentuk perilaku kompetitif antara individu atau kelompok," dan itu "biasanya apa yang terjadi ketika dua pihak atau lebih bersaing tentang tujuan yang tidak sesuai, apakah tujuan tersebut fakta atau persepsi, atau tentang sumber daya yang terbatas " Dengan demikian konflik adalah benturan antara berbagai keinginan yang berbeda tentang tujuan yang sama dan masing-masing pihak berusaha memaksakan kehendaknya pada pihak lain untuk mencapai tujuan yang disengketakan.

\section{KEDUA: KONFLIK INTERNASIONAL ATAS ENERGI}

Persaingan internasional atas sumber daya energi akan menjadi salah satu faktor dan penyebab terpenting dari konflik internasional di masa depan dan yang nampak dalam beberapa waktu terakhir, bahwa krisis internasional ekonomi saat ini terkait dengan kenaikan harga energi dan menipisnya sumber daya tersebut akan Menjadi faktor yang paling menonjol dalam masa depan konflik internasional, kami akan membahas studi tentang konflik internasional atas migas dan konflik sumber air ini.

JURNAL PAPATUNG: Vol. 2 No. 1 Tahun 2019

ISSN: 2715-0186 


\section{Konflik atas Minyak}

Konflik atas kendali atas pasokan minyak yang berharga telah menjadi ciri khas urusan internasional sejak awal abad ke-20. Konflik semacam itu bervariasi sifatnya, mulai dari sengketa teritorial atas kepemilikan minyak- daerah perbatasan yang sarat dengan perjuangan dinasti atau faksi di antara para pemimpin negara-negara kaya minyak hingga perang antar-negara besar atas kendali zona minyak vital. Ketika minyak menjadi semakin langka dan berharga, frekuensi dan tingkat keparahan konflik tersebut kemungkinan besar akan meningkat. 10Menurut statistik EWG: produksi minyak global di dunia telah mencapai puncaknya antara tahun 2008 dan 2011, dan akan berkurang secara bertahap di masa depan. Statistik EWG: 11 kebutuhan minyak dunia pada tahun 2020 akan menjadi 100 juta barel per hari sedangkan produksi tidak akan meningkat sekitar 60 juta barel per tahun. Diperkirakan kenaikan harga minyak di masa mendatang. Statistik EWG juga memperkirakan produksi minyak akan tetap rendah hingga produksi global sekitar 44 juta barel per hari, sedangkan konsumsi akan meningkat menjadi sekitar 115 juta barel per hari. Dunia tidak kehabisan minyak itu sendiri, melainkan kemampuannya untuk menghasilkan minyak berkualitas tinggi yang murah dan dapat diekstraksi secara ekonomis sesuai permintaan. Setelah lebih dari lima puluh tahun penelitian dan analisis tentang masalah ini oleh para ilmuwan yang paling dihormati dan rasional, sekarang jelas bahwa tingkat di mana produsen minyak dunia dapat mengekstraksi minyak telah mencapai tingkat semaksimal mungkin. Inilah yang dimaksud dengan Peak Oil. Dengan usaha dan pengeluaran yang besar, tingkat produksi minyak saat ini mungkin dapat dipertahankan untuk beberapa tahun lagi, tetapi di luar itu produksi minyak harus mulai mengalami penurunan yang permanen dan tidak dapat diubah.

Penurunan minyak di dunia dengan meningkatnya permintaan dan kenaikan harga karena pertumbuhan ekonomi dan munculnya kekuatan internasional baru akan menjadi katalisator konflik di masa depan, ciri-cirinya dimulai di Timur Tengah dan mungkin telah menyebar ke daerah lain. Hubungan erat antara minyak dan konflik berasal dari dua ciri esensial minyak bumi: (1) kepentingan vitalnya bagi ekonomi dan kekuatan militer negara; dan (2) distribusi geografisnya yang tidak teratur.

- Sisi Ekonomi: Minyak adalah mesin utama perekonomian global, yang tidak dapat berlanjut tanpa minyak, merupakan sumber energi utama dunia dan mewakili sekitar 39 persen dari konsumsi energi global, Minyak adalah elemen kunci yang masuk menjadi semua bahan baku berupa plastik, pestisida, cat, pelarut, sumber energi untuk pabrik dan perusahaan serta bahan bakar mobil, 
mesin, dll. Dengan demikian, kurangnya pasokan minyak dunia akan menyebabkan resesi ekonomi, seperti yang terjadi pada tahun 1974. dalam embargo minyak Arab setelah perang Arab-Israel, serta pada 1979 setelah revolusi Iran pada tahun 1990 selama pendudukan Irak di Kuwait.

- Sisi Militer: Minyak bumi juga merupakan faktor vital dalam kekuatan militer suatu negara, karena ia memasok sebagian besar energi yang digunakan untuk menggerakkan tank, pesawat, rudal, kapal, kendaraan lapis baja, dan instrumen perang lainnya, serta kepemilikan dan Penguasaan sumber minyak dan metode yang disediakan mempertimbangkan salah satu faktor terpenting dari kekuatan negara di mana mereka dapat menggunakan minyak sebagai senjata untuk menekan kekuatan pesaing lainnya.

- Distribusi Geografis Tidak Teratur: tempat geografis konsentrasi minyak di dunia adalah tempat terbatas karena minyak terdistribusi di beberapa wilayah di dunia, terutama wilayah Teluk Persia yang mengandung cadangan minyak terbesar di dunia, serta wilayah dan tempat Laut Kaspia Rusia dan Asia Tengah dan beberapa negara di Amerika dan inilah yang membuat konflik internasional terjadi di tempat-tempat yang mengandung sumber daya alam ini dan bahwa lebih banyak perang di dunia setelah Perang Dunia Kedua terjadi di Timur Tengah dan minyak dan gas adalah salah satu penyebabnya. alasan terpenting untuk perang tersebut.

Konflik atas minyak di dunia telah menyebabkan ratusan perang dan konflik internasional dan ras dan etnis dan upaya untuk memecah belah dan baru-baru ini perang di Libya, yang merupakan minyak dari alasan paling penting dan menyebabkan berbagi perusahaan internasional untuk minyak Libya dan upaya untuk membagi Libya dengan pengaruh internasional serta di kawasan Teluk Persia meletus serangkaian perang dan konflik untuk minyak, seperti perang Iran-Irak pada tahun 1980 dan perang Irak melawan Kuwait 1990.

\section{Konflik atas Gas}

Gas alam adalah sumber energi kedua; itu mewakili bagian yang sangat penting, dan terus berkembang, dari sistem energi global. Selama setengah abad terakhir, gas alam telah memperoleh pangsa pasar hampir secara terus menerus, tumbuh dari sekitar 15,6\% dari konsumsi energi global pada tahun 1965 menjadi sekitar $24 \%$ saat ini13. Secara absolut, konsumsi gas alam global selama periode ini telah meningkat dari sekitar 23 triliun kaki kubik (Tcf) pada tahun 1965 menjadi 104 Tcf pada tahun 2009, meningkat lebih dari empat kali lipat.

JURNAL PAPATUNG: Vol. 2 No. 1 Tahun 2019

ISSN: 2715-0186 
Banyak perjuangan internasional di masa depan adalah untuk pengendalian gas dan beberapa di antaranya dimulai di Timur Tengah seperti perang Suriah yang menganggap perang internasional dengan proxy dan tujuan utama perang ini adalah gas alam. Dr.ImadFawziShu'aybi menulis dalam artikelnya (perang gas: konflik di Suriah dan Timur Tengah) bahwa perang Suriah saat ini hanya perang internasional untuk penguasaan dan pembagian cadangan gas di Suriah, katanya: gas adalah yang utama energi di abad 21, baik dari segi energi alternatif hingga penurunan cadangan minyak dunia atau dari segi energi bersih, pengaruh Amerika berakhir sangat lemah dalam menghadapi kekuatan-kekuatan yang sedang berkembang seperti China, India dan Brazil .. Tampak jelas bahwa pencarian kekuasaan tidak lagi dalam persenjataan militer tetapi dalam mencari energi yang memperkuat kekuatan ini.

Suriah adalah episentrum perakitan dan produksi bekerja sama dengan cadangan Lebanon akan menjadi ruang strategis energik terbuka untuk pertama kalinya secara geografis dari Iran ke Mediterania. Rahasia gas Suriah akan membuat semua orang tahu seberapa besar game over gas itu. Siapa yang mengendalikan Suriah bisa mengendalikan Timur Tengah, menguasai Gerbang ke Asia, memiliki Kunci Rumah Rusia, seperti yang dikatakan Catherine ke-2, dan bisa menginjakkan kaki di Jalan Sutra, menurut China. Yang terpenting, mereka yang bisa menembus Syria karena gas memiliki kemampuan untuk menguasai dunia apalagi abad yang akan datang adalah Century Gas. Dan dengan kontrak yang ditandatangani Damaskus untuk mengangkut gas Iran ke Mediterania melalui Irak, ruang geopolitik akan terbuka dan ruang gas akan ditutup di lokasi Nabucco yang dulunya merupakan garis hidup Eropa dan Turki. Suriah, tidak diragukan lagi, akan menjadi kunci dari zaman yang akan datang. Dunia telah berada di ambang perang saat ini karena konflik strategi panas untuk energi gas, yang saat ini menjadi kebutuhan esensial dan tak terelakkan bagi sebagian besar negara di dunia, terutama negara-negara yang tidak memiliki solusi dan alternatif untuk energi tersebut, sehingga mengancam. pecahnya perang untuk gas. Mengingat meningkatnya konsumsi energi, yang telah menjadi sangat diperlukan dalam peradaban modern, energi gas menjadi prioritas strategis untuk pembangunan ekonomi, Siprus hari ini misalnya mencoba menggunakan cadangan gas untuk membuangnya krisis ekonomi karena gas adalah pilihan terakhirnya. Sementara Israel berada di garis depan negara-negara yang ingin berinvestasi dalam energi gas, ladang gas di Mediterania timur, mengapung di lautan ketegangan politik yang berangsur-angsur meningkat, yang mengungkapkan kekhawatiran yang tumbuh yang pada akhirnya dapat mengarah pada perubahan dalam strategi ekonomi untuk Hal inilah yang mendorong semua Negara untuk masuk ke dalam maraton pencarian energi ini dan untuk menemukan metode baru dan strategi

JURNAL PAPATUNG: Vol. 2 No. 1 Tahun 2019

ISSN: 2715-0186 
baru untuk memastikan investasi strategis untuk mendukung ekonomi Namun dengan meningkatnya kebutuhan energi secara cepat, reservasi gas menjadi tidak stabil. Sumber daya gas di dunia terancam akibat tingginya permintaan untuk berbagai keperluan, dan oleh karena itu perkembangan terkini di depan indikator menunjukkan perang strategis yang kuat antara negara-negara gas, yang dapat menciptakan krisis ekonomi yang membuka jalan bagi konflik strategi global di dalam waktu dekat.

\section{KETIGA: HASIL KONFLIK GAS DI TIMUR TENGAH: (TIMUR TENGAH BARU)}

Washington menyadari bahwa dunia di milenium baru telah berubah dan bahwa gas Qatar tidak dapat bersaing di pasar Eropa karena pengaruh Rusia di Eropa meningkat dengan meningkatnya permintaan gas Rusia, yang memonopoli $25 \%$ ekspor ke Eropa, dan ini akan meningkat kekuatan Rusia di Eropa dan di dunia, tidak hanya itu tetapi, Moskow mulai memulihkan pemulihan ekonominya, itulah sebabnya langkah Amerika adalah menyerang World Trade Center di AS sebagai tanggapan atas kekalahan Israel di Lebanon pada tahun 2000 dan kedatangan Putin ke kekuasaan dan konvergensi antara China-Rusia setelah ketegangan berlangsung puluhan tahun selama Perang Dingin, dan jatuhnya beberapa benteng Washington di Amerika Selatan, semua ini merupakan pengenalan awal pendudukan Afghanistan, dan tentu saja tujuan utamanya adalah memotong rute transit dari China, Rusia, dan Iran.

Pada tahun 2002, Amerika membantu Perdana Menteri saat ini (RejepTayyipAurdugan) untuk melakukan kudeta politik terhadap gurunya dan ketua partainya NejmoldinErbakan dan pembentukan partai Islamis dengan nama pembangunan, keadilan, alasan kudeta di Turki adalah alasan yang sama kudeta Qatar (gas adalah alasan kudeta di Turki dan Qatar) di mana Amerika Serikat mulai memasang proyek pipa gas (Nabucco), yang menjangkau dari Laut Kaspia dan wilayah Teluk Persia ke Turki dan Eropa melalui Laut Mediterania. Washington menyadari bahwa gas tidak dapat datang dari Asia Tengah karena tidak dapat masuk dalam perang melawan Iran, oleh karena itu Rusia mengira bahwa proyek pipa Nabucco lahir mati, tetapi Amerika telah berusaha untuk menciptakan Timur Tengah baru dengan partisipasi Turki untuk memecah belah wilayah dan fragmentasi ke sekelompok negara bagian sehingga lebih mudah untuk memperluas proyek ini dan akses ke sumber gas alam.

Nabuccobrings semua wilayah gas di Turki untuk ekspor ke Eropa tanpa melalui Yunani dan dengan demikian Turki beralih ke negara arich melalui transit, yang seharusnya dimulai dengan 31 miliar meter kubik dan hingga 40 miliar meter kubik gas alam untuk alasan ini Mr. Erdogan, yang percaya bahwa akses ke gas Asia Tengah begitu sulit dan tidak mungkin Jadi secara pribadi dia mengunjungi Kairo untuk memanggil

JURNAL PAPATUNG: Vol. 2 No. 1 Tahun 2019

ISSN: 2715-0186 
presiden Mesir untuk penandatanganan perjanjian Nabucco. Di Turki Erdogan dan Gul, mendirikan sebuah partai Islam dengan bantuan AS untuk merebut kekuasaan. Pihak ThenTurkish menerima untuk membagi Mesir menjadi tiga negara dan Irak menjadi tiga negara dan Suriah menjadi empat negara. Washington berusaha membuat pengaruh atas negara-negara Sunni dari negara-negara baru ke Turki Sementara Turki menerima pengaruh Israel di negara-negara baru lainnya. Washington juga berjanji bahwa proyek pipa gas tidak lewat di Yunani untuk memastikan bahwa Turki mendapatkan seluruh pulau Siprus, dan kemudian masuk ke UE dengan mengorbankan Yunani (dan oleh karena itu aneksasi Turki ke payung rudal AS oleh Amerika. ), Itulah mengapa Turki membantu Amerika Serikat di Afghanistan, Iran, dan terutama di Irak dan Suriah. Ini menjelaskan pembentukan (proyek Timur Tengah baru) dan tujuan utama yang berdiri di belakang adalah keinginan untuk mengontrol gas di Tengah. Timur, yang akan menjadi faktor penentu dalam perang yang akan datang.

\section{KEEMPAT: BENTURAN DI ATAS AIR}

Laporan yang dikeluarkan oleh Perserikatan Bangsa-Bangsa pada 23/3/2002 merujuk pada kekurangan air yang serius yang dihadapi dunia, di mana 2,7 miliar orang menderita kekurangan air bersih dan sekitar 5 miliar orang hidup di daerah-daerah yang menghadapi kekurangan air tawar, demikian pula sekitar 5 juta orang setiap tahun karena penyakit yang disebabkan oleh kekurangan air dan laporan tersebut menyimpulkan bahwa sengketa atas air merupakan salah satu penyebab utama konflik internasional di masa depan. Untuk itu jika Peneliti menyepakati label abad duapuluh satu abad minyak dan konflik perebutan minyak, maka konflik perebutan air merupakan ciri utama pada abad dua puluh satu, dimana air merupakan pemasok utama kehidupan sehari-hari ekonomi, sosial dan pertanian di semua negara di dunia dan karena kekeringan yang mendominasi dunia dan kekurangan air, risiko Perang dan konflik tampak hampir mengkhawatirkan masa depan perang di banyak wilayah di dunia di mana meningkatnya permintaan air dalam empat puluh tahun terakhir sebagian besar disebabkan Dengan pertambahan penduduk di dunia dimana jumlah penduduk dunia pada tahun lima puluhan abad terakhir sekitar 2,5 milyar jiwa, dan dua kali lipat jumlah tersebut pada tahun 1990 menjadi sekitar 5,3 milyar, diharapkan dapat mencapai jumlah penduduk dunia pada tahun 2025 menjadi lebih dari 8 miliar, menjadi peningkatan tahunan hingga 90 juta dan ini akan berdampak signifikan pada konsumsi air dunia dan rendahnya per kapita air untuk setiap orang. Laporan lain CIA mengatakan sepuluh daerah calon perang di masa depan karena air utama dari wilayah ini, (Timur Tengah), yang menghabiskan banyak air dalam beberapa dekade terakhir dan banyak negara di Timur Tengah mencoba untuk memperbaiki posisi airnya melalui penarikan air tanah

JURNAL PAPATUNG: Vol. 2 No. 1 Tahun 2019

ISSN: 2715-0186 
atau pembangunan bendungan dan waduk. Asuransi air raksasa, yang berdampak negatif pada negara-negara lain di kawasan yang sama, dan inilah yang menempatkan kawasan itu dalam terang perang masa depan untuk berbagi perairan bersama.

Timur Tengah menganggap salah satu wilayah kandidat paling untuk konflik di masa depan atas air di mana Studi khusus di bidang air merujuk bahwa negara Israel, misalnya, mendapatkan dari luar perbatasannya pada 68\% dari total konsumsi air sementara negara Arab dapatkan hanya 60\% dari luar perbatasannya. Oleh karena itu, masalah air di Timur Tengah memiliki banyak dimensi karena kejadian Timur Tengah di sabuk kering dan semi kering serta kurangnya sumber daya air yang terbarukan dimana sekitar $1 \%$ air di dunia dimana pangsa air per kapita masuk Timur Tengah tidak melebihi 1.744 meter kubik per tahun, sedangkan rata-rata global naik 12.900 meter kubik per tahun dan karena tingkat curah hujan di Timur Tengah antara 5 sampai $450 \mathrm{~mm}$ per tahun sedangkan kisaran curah hujan di Eropa, misalnya, antara 200 hingga $3000 \mathrm{~mm}$ per tahun dan gurun mewakili sekitar $43 \%$ dari total luas Timur Tengah. Oleh karena itu air permukaan seperti sungai merupakan sumber utama air di Timur Tengah dan sebagian besar sungai ini merupakan sungai umum internasional yang dilalui bersama dan melintasi lebih dari satu negara (negara asal, negara pelintas dan negara hilir), sungai Nil Misalnya berasal dari Ethiopia (Danau Victoria) dan melewati sepuluh negara Afrika (Ethiopia - Kenya - Uganda - Rwanda - Burundi - Kongo - Sudan Selatan - Sudan - dan Mesir), serta sungai Tigris dan Efrat, yang berasal dari pegunungan di Turki utara dan kemudian melalui Suriah dan akhirnya ke Irak, oleh karena itu di wilayah perairan yang miskin ini, masing-masing negara mencoba untuk meningkatkan airnya menuju negara lain dan meningkatkan bagiannya dari sungai-sungai bersama dan inilah yang akan memasuki wilayah tersebut mengingat konflik Air tak terhindarkan, di Sungai Nil selama Misalnya, ada rencana untuk membangun bendungan di Sungai Nil di Ethiopia, itu akan dibiayai oleh Bank Dunia dan proyek-proyek ini jika didirikan akan mempengaruhi bagian Mesir dari air Nil hingga 20\% per tahun, tetapi ada juga berencana untuk mengubah semua sumber daya air di wilayah Nil untuk dituangkan ke wilayah Danau Besar Afrika tengah untuk berubah menjadi waduk air raksasa kemudian menjual air ini seperti penjualan minyak bumi, serta untuk sungai Efrat yang dimiliki oleh Tiga negara. yaitu Turki - Syria dan Irak, banyak sekali perbedaan dan permasalahan yang terjadi pada pembagian air sungai tersebut, dimana Turki pada masa lampau menggunakan air sungai Efrat yang mengalir dari Turki melewati Syria untuk politik. tekanan terhadap pemerintah Suriah yang selama tahun sembilan puluhan mendukung PKK melawan rezim Turki, sehingga Turki memiliki rencana untuk pembangunan tiga belas bendungan di Sungai Efrat untuk meningkatkan bagian sungai dan mengurangi

JURNAL PAPATUNG: Vol. 2 No. 1 Tahun 2019

ISSN: 2715-0186 
bagian dari tetangganya, telah mengakhiri proyek pertama adalah Bendungan Ataturk, yang telah mempengaruhi bagian Suriah dari perairan Efrat dan menyebabkan pembentukan konfrontasi militer di akhir tahun sembilan puluhan hingga perselisihan tentang pembagian air. Efrat.

\section{KESIMPULAN}

Dengan pesatnya peningkatan populasi dan pembusukan sumber daya air akibat perubahan iklim, penyalahgunaan kekayaan di Timur Tengah ini, yang semula penuh dengan konflik, konflik nasional, etnis, agama, konflik. Diperkirakan bahwa pecahnya air perang baru selama beberapa dekade mendatang di sebagian Asia dari Timur Tengah, Israel menguasai sebagian besar sumber Air dengan mengorbankan Palestina, Suriah, Yordania, dan proyek bendungan yang didirikan oleh Turki akan berdampak. di Suriah dan Irak kuotasi dari perairan Tigris dan Sungai Efrat. Diharapkan masyarakat di negaranegara ini akan mengalami banyak kekurangan air di tahun-tahun mendatang. Di bagian Afrika dari Timur Tengah, negara-negara penandatangan, (sumber Cekungan Nil) untuk kesepakatan baru untuk berbagi air secara terpisah dari negara-negara hilir (Mesir dan Sudan) mengancam untuk memulai fase baru konflik antara Mesir dan Sudan di satu sisi dan masing-masing Burundi, Kongo, Ethiopia, Kenya, Rwanda, Tanzania dan Uganda di sisi lain. Dengan demikian, pentingnya konflik atas air di Timur Tengah bersumber dari sifat strategi geopolitik untuk Timur Tengah, oleh karena itu isu air di kawasan ini, seperti yang telah dijelaskan sebelumnya tentang pertanyaan-pertanyaan paling umum yang menimbulkan perselisihan dan kontroversi serta konflik di sampingnya. Masalah ekonomi dan sosial, hukum dan teknis, ini adalah masalah strategi keamanan juga, dan pada saat yang sama berkaitan dengan kehidupan negara-negara di kawasan itu dan masyarakat yang terkait dengan masalah lain seperti perbatasan dan perbedaan etnis dan agama. semua yang Israel dan Turki nantikan untuk dibangun peran regional melalui masalah air. Diharapkan air akan tetap menjadi subjek utama di Timur Tengah, fokus utama perhatian dan fokus dalam hubungan antar negara kawasan. Hubungan gesekan akan bermacam-macam bentuknya mulai dari kerjasama dan berakhir dengan konflik bersenjata, ketegangan dan ancaman. Setiap tetes air di Timur Tengah akan menarik setetes darah di masa depan.

\section{DAFTAR PUSTAKA}

Lutz Kleveman, permainan hebat baru, darah dan minyak di Asia Tengah, perpustakaan katalog kongres 2003.

JURNAL PAPATUNG: Vol. 2 No. 1 Tahun 2019

ISSN: 2715-0186 
Teluk Persia Online. "Lembar Fakta Ekspor Minyak dan Gas Teluk Persia (Departemen Energi AS)". 4 Maret 2011.

FACTBOX - 18 negara terdampak oleh deretan gas Rusia-Ukraina ". Reuters. 7 Januari 2009.

Cendrowicz, Leo "Russia-Europe Gas Spat Ends", majalah Time world, (9 Januari 2009.

EIA, Wilayah Laut Kaspia: Survei Statistik dan Perkiraan Minyak dan Gas Utama, Juli 2006.

Chris Arsenault, Laporan oleh al Jazeera, Risiko perang air meningkat seiring kelangkaan, 26 Agustus 2012.

Jamal Ali Salama, analisis hubungan internasional, Studi dalam manajemen konflik internasional, Arab Renaissance House, 2012.

StenVerhoeven, Konflik Bersenjata Internasional dan Non-Internasional, KatholiekeUniversiteitLeuven, Fakultas Hukum, Institut Hukum Internasional, Kertas Kerja No 107 - Maret 2007.

EWG: Kelompok Kerja Lingkungan, perkiraan organisasi lingkungan Amerika 2008.

Raymond Hinnebusch, INVASI AMERIKA DARI IRAK: PENYEBAB DAN KONSEKUENSI Musim Semi 2007.

Masa depan gas alam, 2011 Massachusetts Institute of Technology.

Pasar Gas Alam ". Konferensi PBB tentang Perdagangan dan Pembangunan. 20 September 2008.

ImadFawziShuaibi, Perebutan Timur Tengah: Gas pertama, artikel, Shabakat Voltaire, 17 April 2012 Damaskus.

SahebRubaie, hukum internasional dan aspek perselisihan dan kesepakatan di perairan Timur Tengah, House of Wisdom, Damaskus, mengutip dari surat kabar Timur Tengah, Edisi No. 8547, Ariel 2002

ArnonSofer, konflik atas air di Timur Tengah, Yayasan untuk Masa Depan dan Studi Media, Dar AL Maarifa 2006.

D. Salman Mohammed Ahmed Salman, Bendungan dan sengketa Ethiopia atas air Nil, surat kabar Electronic Sudanaal, 16 Desember 2012.

JURNAL PAPATUNG: Vol. 2 No. 1 Tahun 2019

ISSN: 2715-0186 